\title{
Faults and Fractures in Carbonate Reservoirs: Khuff Formation of Arabian Peninsula
}

\author{
Adel R. Moustafa \\ (Department of Geology, Faculty of Science, Ain Shams University, Cairo 11566, Egypt)
}

Several factors control the distribution of faults and fractures in reservoir rocks. These include the regional stress field, local strain due to the existence of larger structures, deformation history, presentday stress field, diagenetic changes, and mechanical stratigraphy. The regional stress field that affected the eastern part of the Arabian Plate since Permo-Triassic time involved extensional tectonics (leading to development of normal faults) during Permo-Triassic breakup of Gondwana and opening of NeoTethys as well as compressional tectonics (leading to folding, thrusting, and positive structural inversion) at later times (Coniacian to Recent). This stress history led to the development of fold traps (N-S asymmetric folds in east Arabia and NW-SE folds to the north and east). The local strain associated with the fold/fault structures led to the development of small-throw faults dissecting the fold traps as well as several sets of fractures in the Khuff and other reservoirs. Some of these fractures are related to the regional stress field and others are associated with the folds and/or fault-damage zones. Reactivation of the Permo-Triassic normal faults during later phases of compressional tectonics and development of N-S fault-propagation folds was probably associated with trishear deformation in the steep anticlinal flanks leading to additional fracturing of the rocks. The present-day stress field affects both faults and fractures. Critically-stressed faults might lose their lateral seal potential whereas apertures of fractures aligned parallel/sub-parallel to the maximum horizontal stress will be enhanced leading to increased hydrocarbon flow. Diagenetic changes of fractures might lead to filling by mineralizing solutions and decrease in the overall permeability of the reservoir. Also, mechanical stratigraphy is a main factor controlling the fracture density in certain layers.

Previous fracture studies in the Khuff Formation in the Saudi onshore fields indicate two phases of fracturing, an older phase associated with the Permo-Triassic extensional tectonics and a younger phase associated with the Zagros collision tectonics. Although the Khuff reservoir performance depends mainly on matrix porosity (up to $12 \%$ ), some wells show pronounced impact of fractures on reservoir performance where gas production rate is almost double that in wells having only matrix porosity. 